\title{
Evaluation of the Antioxidant Capacity, Antimicrobial and Antiproliferative Potential of Fir (Abies alba Mill.) Honeydew Honey Collected from Gorski kotar (Croatia)
}

\author{
Dalibor Broznić ${ }^{*}$, Ivana \\ Ratkaj², Mladenka \\ Malenica Staver2, Sandra \\ Kraljević Pavelićc,, Paula \\ Žurga ${ }^{4}$, Dragan Bubalo ${ }^{5}$ \\ and Ivana Gobin ${ }^{6}$
}

\section{'Department of Chemistry and} Biochemistry, Faculty of Medicine, University of Rijeka, Braće Branchetta 20, HR-51000 Rijeka, Croatia 2Department of Biotechnology, University of Rijeka, Radmile Matejčić 2, HR-51000 Rijeka, Croatia

${ }^{3}$ Department of Biotechnology, Centre for High Throughput Technologies, University of Rijeka, Radmile Matejčić 2, HR-51000 Rijeka, Croatia

${ }^{4}$ Teaching Institute of Public Health of Primorsko-goranska County, Krešimirova 52a, HR-51000 Rijeka, Croatia

${ }^{5}$ Faculty of Agriculture, University of Zagreb, Svetošimunska 25, HR-10000 Zagreb, Croatia

${ }^{6}$ Department of Microbiology, Faculty of Medicine, University of Rijeka, Braće Branchetta 20, HR-51000 Rijeka, Croatia

Received: 14 January 2018 Accepted: 27 July 2018

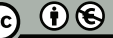

\section{SUMMARY}

The paper examines the antiproliferative, antimicrobial and antioxidative effects of fir (Abies alba Mill.) honeydew honey from mountain region of Croatia (Gorski kotar) as a potential replacement for standard antibiotics and chemotherapeutic agents. Cell viability, annexin $V$ assay and flow cytometry analysis served to analyse the antiproliferative effect on, apoptosis induction in and cell death of cancer cell lines: HeLa, MCF-7, SW620, CFPAC-1, MIA PaCa-2 and normal diploid human fibroblasts (BJ). Antimicrobial activity was tested against Staphylococcus and Acinetobacter strains by agar well diffusion and microdilution assays. The $\mathrm{DPPH}^{\prime}$ assay determined the radical scavenging activity, while mathematical models helped to evaluate the kinetic data of DPPH' inhibition. Antiproliferative effect on all tested cell lines and the prominent effect on normal diploid human fibroblasts (BJ), colorectal adenocarcinoma (SW620, metastatic) and breast epithelial adenocarcinoma (MCF-7, metastatic) was observable. The mechanisms of antiproliferative effect included accumulation of cells in the sub-G1 phase in all tested cells and induction of apoptosis in SW620 and MCF-7 cells predominantly. The antibacterial assays showed that antibiotic-resistant strains of both bacteria, including multi-resistant strain A. baumannii ATCC ${ }^{\oplus}$ BAA$1605^{\mathrm{TM}}$, were sensitive to all tested honey samples. Radical scavenging assay suggests that antioxidants present in the honey possess different radical suppressing abilities and that they react at different rates with radicals, thereby causing two steps of reaction. The results of the study indicate that Croatian fir honeydew honey has a therapeutic potential due to the strong biological activity and can serve to protect human health.

Key words: fir (Abies alba Mill.) honeydew honey, cell cycle, apoptosis, antimicrobial activity, antioxidant capacity, kinetic analysis

\section{INTRODUCTION}

Honey has served as a food and natural promoter of human health from ancient times even though its biological potential has not been understood completely. Nowadays, it is recognized as a worthy therapeutic agent due to its antimicrobial, anti-inflammatory, antioxidant and antitumour properties (1-5). Floral sources and different geographical origin are responsible for different varieties of honey, and are also major contributors to their diverse biological effects (6-11). The main difference is, however, between two types of products known as nectar honey, which derives from nectars of different plants, and the honeydew honey, which bees produce from secretions of plants or excretions of plant-sucking insects found on plants $(9,12,13)$. Different kinds of aphid species like Cinara pectinatae Nördl., Todolachnus abieticola Choi., Mindarus abietinus Koch or Physokermes hemicryphus Dalm. can produce different kinds of honeydew honey (14). One of the most appreciated sorts of honey, fir (Abies alba Mill.) honeydew honey, is produced in the mountain region of Gorski kotar in Croatia $(14,15)$. Honey contains diverse biologically active compounds identified so far. Recent data have shown that mainly polyphenols such as chrysin, galangin, quercetin, kaempferol, acacetin, pinocembrin, pinobanksin, caffeic acid and apigenin possess potential biological activity $(16,17)$. Various types of honey have promising biological properties and exert selective cytotoxicity, which is opposed to non-selective and 
cytotoxic effects observed for current chemotherapy agents (18). Additionally, honey's antibacterial potential is gaining importance as the number of antibiotic-resistant bacteria is increasing constantly, posing a serious health threat. Especially dangerous are strains of bacteria that are highly resistant to antibiotics, namely methicillin-resistant Staphylococcus aureus (MRSA) or multidrug-resistant Acinetobacter baumannii. Therefore, discovery of alternative antibiotic therapeutic agents is an urgent matter. Furthermore, honeydew honey has higher mineral and vitamin content than the nectar honey. Such composition causes a darker colouring, indicating a generally better antioxidant property than lighter honey types (19). Honey flavonoids are mainly responsible for its antioxidant characteristics along with phenolic acids, catalase, peroxidase, carotenoids and non-peroxidal components (20).

In recent years there has been an increasing interest in the use of food rich in antioxidant components that may improve the general condition of patients and their immune status with chronic diseases and diseases that have no cure, i.e. inflammation and cancer (21). Honey may present such food as it possesses positive biological properties even though the mechanism and magnitude of effects are still insufficiently investigated. As a contribution to better understanding of honey biological properties, the objective of this study is to investigate: (i) in vitro antiproliferative activity on five tumour cell lines and normal human fibroblasts, (ii) in vitro antimicrobial activity against drug-resistant bacteria A. baumannii and S. aureus, (iii) antioxidative activity against 2,2-diphenyl-1-picrylhydrazyl (DPPH') and (iv) kinetic analysis of $\mathrm{DPPH}^{-}$inhibition by mathematical models of fir (Abies alba Mill.) honeydew honey from different locations of the mountain region Gorski kotar (Croatia).

\section{MATERIALS AND METHODS}

\section{The honeydew honey samples}

The honey samples were purchased from Gorski d.o.o., Fužine, Croatia. They were obtained during summer 2014 from different geographic areas in the mountain region Gorski kotar (western part of Croatia) defined by Universal Transverse Mercator (UTM) system coordinates as follows: $45^{\circ} 17^{\prime} 59^{\prime \prime} \mathrm{N}$,

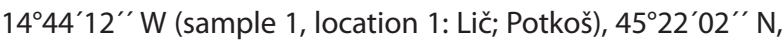
$14^{\circ} 43^{\prime} 10^{\prime \prime} \mathrm{W}$ (sample 2, location 2: Crni lug; Lazac), 45¹9'34" N, 14 ${ }^{\circ} 42^{\prime} 16^{\prime \prime} \mathrm{W}$ (sample 3, location 3: Fužine; Vrelo) and $45^{\circ} 25^{\prime} 16^{\prime \prime} \mathrm{N}, 14^{\circ} 42^{\prime} 26^{\prime \prime} \mathrm{W}$ (sample 4, location 4: Crni lug; Vrelo)) were stored at $4{ }^{\circ} \mathrm{C}$ in hermetically closed glass bottles until the analysis. The melisopalynological analysis followed the methods recommended by the International Commission for Bee Botany (now known as International Commission on Plant Pollinator Relations; ICPPR) (22). Microscopic analysis for morphometry of pollen grains and honeydew elements such as mould hyphae, fungal spores, mycelium or unicellular algae was performed on a Hund H500 (Helmut Hund GmbH, Wetzlar, Germany) light microscope with attached digital camera (model Dino-Eye AM423U; Dino-Lite, AnMo Electronics Corp., Hsinchu,
Taiwan) and coupled to an analysis system (DinoCapture $2.0 \mathrm{v}$. 1.4.9; Dino-Lite). Water content was determined by refractometry, measuring the refractive index, using standard model Abeé refractometer (Carl Zeiss, Jena, Germany) at $20^{\circ} \mathrm{C}$. Water content (\%) was obtained from the Chataway table (23). Electrical conductivity was measured in a solution of $20 \mathrm{~g}$ honey sample in low-conductivity water system at $20^{\circ} \mathrm{C}$ using conductometer (HI-8733; Hanna Instruments, Woonsocket, RI, USA), while the ash content was calculated according to the results of electrical conductivity (24).

For metal analysis, honey samples were digested by the Anton Paar Multiwave 3000 microwave system (Perkin Elmer Instruments, Waltham, MA, USA) equipped with pressurized vessels, using $5 \mathrm{~mL}$ of $65 \%$ nitric acid (Suprapur, Merck, Darmstadt, Germany) per approx. $1 \mathrm{~g}$ of each sample, over a 20-minute operation cycle at $200^{\circ} \mathrm{C}$. The digested samples were then transferred to $25-\mathrm{mL}$ volumetric flasks and ultrapure water (Siemens Water Technologies Corp, Warrendale, PA, USA) was added to the mark. The mass fractions of $\mathrm{Na}, \mathrm{K}, \mathrm{Mg}, \mathrm{Ca}, \mathrm{Cu}, \mathrm{Zn}, \mathrm{Fe}, \mathrm{Ni}$, $\mathrm{Mn}$ and $\mathrm{Al}$ were determined using the inductively coupled plasma optical emission spectroscopy (ICP-OES) Optima 8000 equipped with S10 autosampler (Perkin Elmer Instruments). Analytical blanks were prepared and run in the same way as the samples. The mass fractions of metals were determined using external standards, with standard solutions prepared in the same acid matrix. Standards for the instrument calibration were prepared on the basis of multielement certified standard solution for ICP (Perkin Elmer Instruments).

\section{Antitumour activity assay}

The ATCC (American Type Culture Collection, Manassas, VA, USA) human cell lines: HeLa (cervical carcinoma), SW620 (colorectal adenocarcinoma, metastatic), MCF-7 (breast epithelial adenocarcinoma, metastatic), MIA PaCa-2 (pancreatic carcinoma), CFPAC-1 (pancreatic adenocarcinoma, derived from metastatic liver) and BJ (normal diploid human fibroblasts) were cultured as monolayers and maintained in Dulbecco's modified Eagle medium (DMEM; Lonza, Verviers, Belgium) supplemented with $10 \%$ foetal bovine serum (Gibco Invitrogen, Thermo Fisher Scientific, Waltham, MA, USA), 2 $\mathrm{mM}$ L-glutamine (Lonza), $100 \mathrm{U} / \mathrm{mL}$ penicillin and $100 \mathrm{mg} /$ $\mathrm{mL}$ streptomycin in a humified atmosphere with $5 \% \mathrm{CO}_{2}$ at $37{ }^{\circ} \mathrm{C}$ and subcultured every $3-4$ days using $0.25 \%$ trypsin, $0.02 \%$ EDTA solution (Lonza ${ }^{\mathrm{TM}}$ BioWhittaker ${ }^{\mathrm{TM}}$ TrypZean $^{\mathrm{TM}}$ EDTA Solution, Lonza). For antitumour analysis of honey samples, the panel of cell lines was inoculated into Falcon 96-well microtiter flat bottom plates (Becton, Dickinson and Company (BD), Franklin Lakes, NJ, USA) on day 0, at 3000-5000 cells per well according to the doubling times of specific cell line. After $24 \mathrm{~h}$, the cells were treated with freshly prepared honey samples in DMEM (samples $1-4,500 \mathrm{mg} / \mathrm{mL}$ stock solution) in five different final concentrations: 2, 7, 15, 30 and $50 \mathrm{mg} /$ $\mathrm{mL}$. The $\mathrm{pH}$ value of the samples was measured and the addition of honey did not alter the $\mathrm{pH}$ value of cultivating medium. After $72 \mathrm{~h}$ of incubation, cell viability was determined by 
3-(4,5-dimethylthiazol-2-yl)-2,5-diphenyltetrazolium bromide (MTT; Sigma-Aldrich, Merck, St. Louis, MO, USA) colorimetric assay. The percentage growth and $I C_{50}$ (concentration causing $50 \%$ growth inhibition) values for honey samples were calculated as described previously $(25,26)$.

\section{Cell cycle analyses}

A total of $1.5 \cdot 10^{5}$ cells/well was seeded in a six-well plate (Sarstedt, Newton, NC, USA). After 24 h, the cells were treated with the honey sample that had the most potent antiproliferative effect at $I C_{50}$ concentration and $5 \cdot I C_{50}$ (BJ with sample 2 at 4.44 and $22.2 \mathrm{mg} / \mathrm{mL}$, SW620 with sample 3 at 7.96 and 39.8 $\mathrm{mg} / \mathrm{mL}$ and MCF-7 cells with sample 4 at 9.94 and $49.7 \mathrm{mg} /$ $\mathrm{mL}$ ). Attached cells were trypsinized, combined with floating cells, washed with phosphate buffer solution (Gibco, Invitrogen, Thermo Fisher Scientific, Waltham, MA, USA) and fixed with $70 \%$ ethanol (Kemika, Zagreb, Croatia) after 24 and 48 $\mathrm{h}$ of incubation. The cells were stained and analysed with $\mathrm{BD}$ FACSCalibur $^{\mathrm{TM}}$ flow cytometer (BD Biosciences, San Jose, MA, USA) as described in our previously paper (26).

\section{Annexin Vassay}

Detection and quantification of apoptotic cells at single cell level was performed using eBioscience ${ }^{\mathrm{TM}}$ Annexin V-FITC apoptosis detection kit (Thermo Fisher Scientific), according to the manufacturer's recommendations. Cells were seeded in Petri dishes ( $10^{6}$ cells/plates), and treated with the most effective honey sample (lowest $\mathrm{IC}_{50}$ value) and after $48 \mathrm{~h}$ were analysed with BD FACSCalibur (BD Biosciences) flow cytometer as described previously (26).

\section{Bacterial strains and preparation of bacterial suspension}

The standard laboratory strains Staphylococcus aureus ATCC 25923, Acinetobacter baumannii (ATCC BAA-1605 and ATCC 19606), several clinical isolates (56781, 54531, 53154 and 771) as well as S. aureus, two methicillin-resistant S. aureus (MRSA) strains, S. epidermidis and one methicillin-resistant S. epidermidis (MRSE) strain from our culture collection were used in the study. Four clinical A. baumannii strains (56781, 54531, 53154 and 771) were kindly provided by Prof. Marina Bubonja Šonje from the Department of Clinical Microbiology, University Hospital Rijeka, Rijeka, Croatia. Bacteria were cultured at $37^{\circ} \mathrm{C}$ for $24 \mathrm{~h}$ in Mueller-Hinton broth (MHB) (Oxoid, Hampshire, UK). The absorbance of the bacterial suspension was additionally estimated using a spectrophotometer (Eppendorf BioPhotometer, AG Eppendorf, Hamburg, Germany) at $550 \mathrm{~nm}$, and number of bacterial cells was extrapolated from a standard growth curve. The viable bacterial count used in experiments was obtained by plating 10-fold dilutions onto blood agar (Biolife, Milano, Italy). After incubating the plates for $24 \mathrm{~h}$ at $37^{\circ} \mathrm{C}$, the number of bacteria was calculated as colony forming units (CFU)/mL. Starting inoculum for all experiments was approx. $1.5 \cdot 10^{6} \mathrm{CFU} / \mathrm{mL}$.

\section{Antibacterial activity assay}

Antimicrobial effect of honey samples was determined using agar well diffusion and broth dilution methods. Susceptibility tests were made according to the European Committee for Antimicrobial Susceptibility Testing (EUCAST) guidelines (27). Each honey sample was dissolved in MHB to prepare stock solutions of $0.8 \mathrm{~g} / \mathrm{mL}$. Furthermore, twofold serial dilutions in MHB were prepared from stock solutions of each honey sample to give final concentrations ranging from 0.0125 to $0.4 \mathrm{~g} / \mathrm{mL}$.

\section{Agar well diffusion assay}

For the agar well diffusion assay, bacterial cells from an exponential phase culture obtained from a single colony were spread onto the surface of Mueller-Hinton agar (MHA) plates (Difco) using sterile swab. The wells of $6 \mathrm{~mm}$ in diameter were then cut with sterile borer in the agar and filled with $50 \mu \mathrm{L}$ of honey sample (concentration $0.8 \mathrm{~g} / \mathrm{mL}$ ). After overnight incubation at $37^{\circ} \mathrm{C}$, the plates were examined and antimicrobial activity was evaluated by measuring the diameter of the growth inhibition zone around the well. All tests were done in duplicate. For positive control, the vancomycin (5 $\mu$; Sigma-Aldrich, Merck) and meropenem (10 $\mu$; Sigma-Aldrich, Merck) discs were placed on the MHA with bacteria and after overnight incubation at $(35 \pm 2)^{\circ} \mathrm{C}$, the zone of inhibition was measured and interpreted per the EUCAST guidelines (27). For vancomycin, the disc diffusion is considered unreliable and the zone diameter break point is not available. The zone diameter breakpoint for meropenem against Acinetobacter (resistance $\geq 15 \mathrm{~mm}$, susceptibility $\leq 21 \mathrm{~mm}$ ) was evaluated.

\section{Microdilution assay}

Minimum inhibitory (MIC) and minimum bactericidal concentrations (MBC) of the honey samples were determined using a standard microdilution technique in MHB. Series of twofold dilutions of honey samples in MHB were performed in sterile 96 -well microtiter plates. A volume of $100 \mu \mathrm{L}$ of each sample diluted in the concentration ranging from 0.025 to 0.8 $\mathrm{g} / \mathrm{mL}$ was mixed with equal volume of bacterial suspension. Positive (broth and inoculum) and negative (simple broth) growth controls were prepared. The plates were incubated for $24 \mathrm{~h}$ at $37^{\circ} \mathrm{C}$ and $120 \mathrm{rpm}$ (Unimax 1010; Heidolph Instruments GmbH\&CO. KG, Schwabach, Germany). MIC values were taken as the lowest concentration of honey sample (highest dilution) that produced no visible bacterial growth (no turbidity) compared to the control tubes after $24 \mathrm{~h}$ of incubation at $37^{\circ} \mathrm{C}$. MBC is measured by inoculating the broth used for MIC determinations onto blood agar and incubating further for 18-24 h. MBC was defined as the lowest concentration of honey sample that killed $\geq 99 \%$ of bacteria instead of yielding negative subcultures on the solid medium. Vancomycin for Staphylococcus spp. and meropenem for A. baumannii strains served as positive controls of growth inhibition. The final antibiotic concentrations used in the assays ranged 
between 0.00004 and $0.032 \mathrm{mg} / \mathrm{mL}$ for both antibiotics. The results were interpreted following EUCAST recommendations (27). The MIC breakpoint for vancomycin against $S$. aureus is when resistance is $\geq-0.002 \mathrm{mg} / \mathrm{mL}$ and susceptibility $\leq 0.002$ $\mathrm{mg} / \mathrm{mL}$, and for coagulase-negative staphylococci when resistance is $\geq 0.004 \mathrm{mg} / \mathrm{mL}$ and susceptibility $\leq 0.004 \mathrm{mg} / \mathrm{mL}$. Meropenem breakpoint against $A$. baumannii is susceptible if its MIC is $\leq 0.002 \mathrm{mg} / \mathrm{mL}$, and resistant if it is $\geq 0.008 \mathrm{mg} / \mathrm{mL}$.

\section{Radical scavenging activity and kinetic analysis}

The radical scavenging activity of honey samples was determined using the DPPH' assay (Sigma-Aldrich Chemie, Merck, Taufkirchen, Germany) according to the procedure described by Piljac-Žegarac et al. (28). All samples were dissolved in distilled water to obtain $5 \%(\mathrm{~m} / \mathrm{V})$ solution. Then, 1 $\mathrm{mL}$ of each honey solution was mixed with $3 \mathrm{~mL}$ of $0.1 \mathrm{mmol} / \mathrm{L}$ methanolic DPPH' solution. The reduction of the $\mathrm{DPPH}^{\prime}$ radical was determined by measuring the absorbance of the mixture at $515 \mathrm{~nm}$ using UV-VIS spectrophotometer $(\mathrm{HACH}$ DR/4000; HACH Company, Loveland, CO, USA) against methanol as blank and monitored at every minute (for kinetic analysis) during $60 \mathrm{~min}$. The capability to scavenge the $\mathrm{DPPH}^{\circ}$ radical was expressed as a percent of radical inhibition by samples and calculated according to the following equation:

$$
\mathrm{DPPH} \text { inhibition }=\frac{A_{\text {control }}-A_{\text {sample }}}{A_{\text {control }}} \cdot 100
$$

where $A_{\text {control }}$ and $A_{\text {sample }}$ are the absorbance of the methanol DPPH 'solution without the sample as negative control at $t=0$ min and the absorbance of the sample at $t=60 \mathrm{~min}$, respectively. The extent of DPPH inhibition was compared with a standard curve of Trolox (6-hydroxy-2,5,7,8-tetramethylchroman-2-carboxylic acid, Trolox, Sigma-Aldrich Chemie, Merck) in the range $0-0.21 \mathrm{mmol} / \mathrm{L}$. Quantitative analysis of radical scavenging was expressed in mmoles of Trolox equivalents (TE) per kilogram of honey according to the following equation:

$$
\left(\frac{n(\mathrm{TE})}{m(\text { honey })}\right)=\frac{c(\mathrm{TE}) \cdot V(\text { solution }) \cdot 1000}{m(\text { honey })}
$$

where $c(T E)$ is concentration of Trolox from the calibration line equivalent to the $\mathrm{DPPH}^{\circ}$ inhibition of honey solution, $V$ is the total volume $(\mathrm{mL})$ of honey solution $(10 \mathrm{~mL})$, and $m$ is mass (g) of honey sample.

The kinetic data analysis of DPPH inhibition was evaluated by seven mono- (Eqs. 3-5) and biphasic (Eqs. 6-9) mathematical models:

Zero-order model:

$$
A_{\mathrm{t}}=A_{0}+k_{0} \cdot t
$$

Single first-order model:

$$
A_{\mathrm{t}}=A_{0} \cdot \mathrm{e}^{-\mathrm{k}_{1} \cdot \mathrm{t}}
$$

Logarithmic model:

$$
A_{\mathrm{t}}=A_{0} \cdot \mathrm{e}^{-\mathrm{k}_{1} \cdot \mathrm{t}} \cdot \mathrm{c}
$$

Weibull distribution model:

$$
A_{\mathrm{t}}=A_{0} \cdot \mathrm{e}^{\left[-\mathrm{k}_{\mathrm{a}} \cdot \mathrm{t}^{\beta}\right]}
$$

First-order double exponential model:

$$
A_{\mathrm{t}}=A_{1} \cdot \mathrm{e}^{-k_{1} t}+A_{2} \cdot \mathrm{e}^{-k_{2} \cdot t}+A_{r}
$$

First-order discontinuous model:

$$
A_{\mathrm{t}}=A_{1} \cdot \mathrm{e}^{-\mathrm{k}_{1} \cdot \mathrm{t}_{1}}+A_{2} \cdot \mathrm{e}^{-\mathrm{k}_{2} \cdot \mathrm{t}_{2}}
$$

Gustafson and Holden model:

$$
A_{\mathrm{t}}=A_{0}\left(\frac{\mathrm{t}}{\beta}+1\right)^{-\mathrm{k}_{a}}
$$

where $A_{0^{\prime}} A_{t^{\prime}} A_{1}, A_{2}$ and $A_{r}$ are the ratios of absorbance at the beginning of the experiment, at time $t$, in phases 1 and 2 at time $t=0$ and the remaining value, respectively, $k_{0}, k_{1}$ and $k_{2}$ are kinetic constants, $k_{a}$ and $\beta$ are shape and location parameters, respectively, $t, t_{1}$ and $t_{2}$ are the reaction time, time of the first and second phase of reaction, respectively. Curves obtained with predicting models were plotted with the non-linear regression procedures, available with Wolfram Research Mathematica ${ }^{\circledR}$ software package v. 9.0 (29).

\section{Statistical analysis}

Descriptive statistical analyses as well as all other statistical calculations were performed using the commercial software Statistica v. 13.0 (30) at the $p<0.05$ level of significance. All assays, cell cycle analysis, annexin $V$ and antibacterial analysis were performed at least in duplicate (antitumour activity assays were performed in quadruplicate in three individual experiments), and the results were expressed as the mean \pm standard deviation. Statistical analysis of antibacterial activity was analysed by Kruskal-Wallis test and differences between sensitive and resistant strains by Student's t-test while cell cycle analysis and annexin $\mathrm{V}$ assay were analysed by one way ANOVA test with post hoc comparison (Tukey's and Duncan's tests).

The goodness of fit of the tested mathematical models to the experimental data was evaluated by the coefficient of determination $\left(R^{2}\right)$, the scaled root mean squared error (SRMSE; Eq. 10), and error of chi-square test ( $\chi^{2}$ error; Eq. 11):

$$
\begin{gathered}
\text { SRMSE }=\frac{1}{A_{\text {exp }, i}} \sqrt{\frac{\sum_{i=1}^{N}\left(A_{\text {exp }, i}-A_{\text {pred }, i}\right)^{2}}{N}} \\
\chi^{2} \text { error }=100 \cdot \sqrt{\frac{1}{\chi_{\text {tabulated }}^{2} \sum_{i=1}^{N} \frac{\left(A_{\text {exp }, i}-A_{\text {pred }, i}\right)^{2}}{A_{\text {exp }, i}^{2}}}}
\end{gathered}
$$

where $A_{\exp }$ and $A_{\text {pred }}$ are experimental and predicted data respectively, $\overline{A_{\text {exp, }}}$ is the mean of all experimental data, and $N$ number of measurements. Dependence of kinetic rate constants and the radical scavenger capacity (TEAC) were tested by a nonparametric correlation test (Kendall's Tau) and by multiple linear regression analysis.

\section{RESULTS AND DISCUSSION}

\section{Results of honey sample analyses}

Pollen grain and honey elements of all tested honey samples (1-4) were assessed microscopically, with their ratio $>3$ confirming that all tested honey samples belonged to fir 
honeydew honey $(13,22,31)$. Their water content was within the limits according to the Codex Alimentarius and to the EU Draft 96/0114 (CNS) ( $\leq 21 \%$ ) (24), except for sample 1, which had a slightly higher percentage of water (21.5\%; Table 1 ). This can cause fermentation of honey during storage. Variation in the water content may be caused by various factors, such as harvesting season, the degree of maturity reached in the hive and environmental factors $(32,33)$. Bertoncelj et al. (34) and Kropf et al. (35) found lower water values (15.2\%) in Slovenian fir honeydew honey than in our study. Karabagias et al. (11) studied characterisation of Greek pine honeydew honey samples depending on their geographical origin and they found water content between 10.5 to $20.5 \%$. Furthermore, Malika et al. (36) reported the water content up to $21.8 \%$ in Moroccan honey, while Kuś et al. (37) found $16.7 \%$ and Rybak-Chmielewska et al. (38) $16.8 \%$ in Polish honeydew honey.

Other honey quality parameters are ash content and electrical conductivity, which depend on the mineral content of the honey and give inorganic residue and ionisable organic and inorganic substances, respectively (39). The ash mass fraction is a useful parameter in determining botanical origin of honey and differentiating between nectar and honeydew honey, as values below $0.6 \%$ are expected for nectar honey (40-42). The ash content of our honey samples was in the range from 0.57 to $0.62 \%$ (Table 1), which is in accordance with the Codex Alimentarius and EU Draft ( $\leq 1.2 \%)(24)$. Karabagias et al. (11) found similar ash values (0.31-0.92 \%) in Greek honeydew honey, Pérez Martin et al. (43) in Spanish honeydew honey (0.81\%), and Kropf et al. (35) in Slovenian honeydew honey ( $0.55 \%)$. The electrical conductivity values of our samples ranged from 1.14 to $1.22 \mathrm{mS} / \mathrm{cm}$ (Table 1), which is in accordance with the legislation (>0.8 ms/ $\mathrm{cm})(24,44)$. These values are in agreement with the values for honeydew honey (from 0.80 to $1.3 \mathrm{mS} / \mathrm{cm}$ ) from different geographical regions (Croatia, Macedonia, Slovenia and New Zealand) (35,45-47). Tuberoso et al. (48) found an extremely high value of electrical conductivity $(3.07 \mathrm{mS} / \mathrm{cm})$ in their research of biodiversity of Salix spp. honeydew honey. Karabagias et al. (11) reported electrical conductivity values between 0.414 and $1.748 \mathrm{mS} / \mathrm{cm}$ in Greek pine honeydew honey, depending on the geographical region. Likewise, similar to the results of our study, Pérez Martin et al. (43) found values of electrical conductivity of $1.02 \mathrm{mS} / \mathrm{cm}$ in honeydew honey from the northwest of Spain, and Kuś et al. (37) $1.2 \mathrm{mS} / \mathrm{cm}$ and Rybak-Chmielewska et al. (38) $1.14 \mathrm{mS} / \mathrm{cm}$ in Polish honeydew honey. Greater mineral content is characteristic for honeydew honey and the most abundant elements were $\mathrm{K}, \mathrm{Ca}, \mathrm{Na}, \mathrm{Mg}$, followed by Al, Fe, Mn, Cu, Zn and Ni. Metal content varies depending on geographical and botanical origin. The highest values of $\mathrm{K}$ are similar to some Malaysian honey types (trigona and tualang) and avocado honey from Spain. High concentrations of $\mathrm{Ca}, \mathrm{Na}$ and $\mathrm{Mg}$ are also reported in other types of honey $(49,50)$. Some metals present in the analysed samples play important roles in body functions, such as Fe, Mg, Zn and $\mathrm{Mn}$, and the consumption of honeydew honey might have a direct benefit for humans.

\section{Antiproliferative and antibacterial effect of fir honeydew honey samples}

Results of antiproliferative assay of honey samples showed inhibitory effects on all tested cell lines, in a dose-dependent manner (Table 2 shows IC $C_{50}$ values). All four samples had an effect on BJ, HeLa, CFPAC-1 and MIA PaCa- 2 cells at almost similar $\mathrm{IC}_{50}$.

For an additional analysis of cell cycle changes, two cancer cell lines (SW620 and MCF-7) along with normal BJ fibroblasts were chosen and treated with honey sample (at $\mathrm{IC}_{50}$ ) for 24 and $48 \mathrm{~h}$. Samples with the lowest IC $\mathrm{C}_{50}$ were chosen for additional analyses. BJ, SW620 and MCF-7 cell lines were treated with samples 2, 3 and 4, respectively, and changes in the cell cycle were monitored. Lower concentrations that correspond to $I C_{50}$ values had almost no effect on the cell cycle of cancer cell lines SW620 and MCF-7 after 24 and $48 \mathrm{~h}$ of incubation. Five times higher concentrations, on the other hand, caused significant changes, especially in the sub-G1 phase, indicative of cell death (Table 3). An increased number of SW620 cells was in the sub-G1 phase (more than $18 \%$ ) after $48 \mathrm{~h}$, while a 24 and $30 \%$ increase of the same MCF-7 cells was observable after 24 and $48 \mathrm{~h}$, respectively. Normal human fibroblasts (BJ) treated with a higher concentration of honey sample 2 $(22.20 \mathrm{mg} / \mathrm{mL})$ had the greatest increase (almost $30 \%)$ in the number of cells in the sub-G1 phase after $24 \mathrm{~h}$ and over 50 $\%$ after $48 \mathrm{~h}$. Concomitantly with the sub-G1 cell percentage increase, a decrease in G1 phase was observed in the MCF-7 cell line after $24 \mathrm{~h}$ with a consequent increase of cells in the $\mathrm{S}$ phase after $48 \mathrm{~h}$ of treatment. Higher concentration of honey sample $3(39.8 \mathrm{mg} / \mathrm{mL})$ caused uniform changes in SW620 cell cycle, affecting both $\mathrm{G} 1$ and $\mathrm{S}$ phases (increased cell number in G1 and decreased cell number in the S phase) after 24

Table 1. The electrical conductivity ( $\kappa$ ), ash, water and metal ion content of fir (Abies alba Mill.) honeydew honey

\begin{tabular}{|c|c|c|c|c|c|c|c|c|c|c|c|c|c|}
\hline \multirow{2}{*}{$\begin{array}{l}\text { Honey } \\
\text { sample }\end{array}$} & \multirow{2}{*}{$\begin{array}{c}K / \\
(\mathrm{mS} / \mathrm{cm})\end{array}$} & \multirow{2}{*}{$w($ ash $) / \%$} & \multirow{2}{*}{$w($ water $) / \%$} & \multicolumn{10}{|c|}{$w($ metal ion $) /(\mathrm{mg} / \mathrm{kg})$} \\
\hline & & & & $\mathrm{Na}$ & $\mathrm{Mg}$ & K & $\mathrm{Ca}$ & $\mathrm{Ni}$ & $\mathrm{Cu}$ & $\mathrm{Fe}$ & $\mathrm{Zn}$ & $\mathrm{Mn}$ & $\mathrm{Al}$ \\
\hline 1 & 1.22 & 0.62 & 21.5 & 37.19 & 60.13 & 2406.00 & 82.35 & 0.30 & 1.18 & 2.83 & 0.82 & 2.85 & 19.80 \\
\hline 2 & 1.17 & 0.59 & 18.4 & 34.99 & 95.16 & 2491.00 & 110.30 & 0.34 & 1.80 & 4.31 & 0.41 & 2.63 & 16.19 \\
\hline 3 & 1.22 & 0.62 & 17.7 & 185.90 & 75.57 & 2778.00 & 717.70 & 0.34 & 1.76 & 2.32 & 1.43 & 2.32 & 17.88 \\
\hline 4 & 1.14 & 0.57 & 19.7 & 48.95 & 74.04 & 2372.00 & 111.80 & 0.19 & 1.45 & 9.51 & 1.88 & 2.35 & 10.67 \\
\hline
\end{tabular}


Table 2. The growth inhibitory concentrations $\left(\mathrm{IC}_{50} /\right.$ ) of fir (Abies alba Mill.) honeydew honey that inhibit the normal human skin fibroblasts (BJ), cervical carcinoma (HeLa), breast epithelial adenocarcinoma, metastatic (MCF-7), colorectal metastatic adenocarcinoma (SW620), pancreatic carcinoma derived from metastatic liver (CFPAC-1) and pancreatic carcinoma (MIA PaCa-2)

\begin{tabular}{|c|c|c|c|c|c|c|}
\hline \multirow{3}{*}{$\begin{array}{l}\text { Honey } \\
\text { sample }\end{array}$} & \multicolumn{6}{|c|}{$\mathrm{IC}_{50} /(\mathrm{mg} / \mathrm{mL})$} \\
\hline & \multicolumn{6}{|c|}{ Cell line } \\
\hline & BJ & HeLa & MCF-7 & SW620 & CFPAC-1 & MIA PaCa-2 \\
\hline 1 & 4.50 & 18.51 & 13.27 & 12.01 & 19.98 & 17.67 \\
\hline 2 & 4.44 & 19.03 & 10.54 & 13.55 & 19.63 & 16.83 \\
\hline 3 & 5.12 & 17.50 & 11.54 & 7.96 & 19.15 & 16.80 \\
\hline 4 & 4.64 & 16.34 & 9.94 & 10.06 & 18.29 & 16.72 \\
\hline
\end{tabular}

$\mathrm{IC}_{50}=$ concentration required for inhibition of tumour cell proliferation by $50 \%$

and $48 \mathrm{~h}$. The same phases were affected in BJ cells as well, where higher concentrations caused a decreased number of cells in the $\mathrm{G} 1$ phase after $48 \mathrm{~h}$, while both tested concentrations caused increased number of cells in the $\mathrm{S}$ phase after $48 \mathrm{~h}$. These results point to a uniform mechanism of action on the cell cycle of the tested cells, in particular induction of cell death, i.e. apoptosis.

Activation of apoptosis was therefore additionally analysed in BJ, SW620 and MCF-7 cells after $48 \mathrm{~h}$ of treatment. Apoptosis was confirmed in all tumour cells treated with honey samples. Interestingly, honey sample 3 primarily increased the number of SW620 cells in early apoptosis (more than 30 $\%$, while honey sample 4 treatment of MCF-7 brought about increase in early and late apoptosis for almost $20 \%$. Since BJ cells had the highest number of cells in the sub-G1 phase, it was interesting to observe that only a slight increase of cell number was measured in early and late apoptosis (5 and $1 \%$ respectively), which is considerably lower than of cancer cell lines. Thus, it is possible that another mechanism of cell death occurs in these cells.

Moreover, our results showed that honey samples from Gorski kotar had antiproliferative properties on a panel of tumour cell lines and normal fibroblasts. The obtained IC $\mathrm{C}_{50}$ values in this study show a higher activity of tested honeydew honey samples than the honey reported in the literature. For example, Wen et al. (51) showed that gelam honey and nenas honey with $\mathrm{IC}_{50}$ values 39.0 and $85.5 \mathrm{mg} / \mathrm{mL}$, respectively, inhibited HT29 colon cancer cells. Similar research investigating synergistic effect of gelam honey and ginger on HTC 116 colorectal cancer cells showed that $I C_{50}$ value of gelam honey was $75 \mathrm{mg} / \mathrm{mL}$ (52). In accordance with these data, our previous results for Satureja montana L. honey (26) also point to higher $\mathrm{IC}_{50}$ values $(28-45 \mathrm{mg} / \mathrm{mL})$ than of honeydew honey tested in this study. Contrary to these results, Seyhan et al. (53) reported lower $\mathrm{IC}_{50}$ values of tree-originating honey types (chestnut, pine and cedar), ranging from approx. 2.5-5 $\mu \mathrm{g} / \mathrm{mL}$, against different breast cancer cell lines (MCF-7, MDA-MB-231 and SKBR-3). Three samples with the lowest IC ${ }_{50}$ values, samples 2, 3 and 4, were chosen for additional biological studies. The analysis of the cell cycle showed a marked increase in the number of cells in the sub-G1 phase, indicative of apoptosis. Activation of apoptosis was confirmed by annexin $\mathrm{V}$ test, which showed an increased number of SW620 cells primarily in early apoptosis, and increased early and late apoptotic MCF-7cell number after $48 \mathrm{~h}$ of treatment with samples 3 and 4, respectively. A number of other investigations also proposed apoptosis as a possible mechanism for observed

Table 3. Flow cytometry analysis of normal human skin fibroblasts (BJ), colorectal metastatic adenocarcinoma (SW620) and breast epithelial adenocarcinoma (MCF-7) treated with fir (Abies alba Mill.) honeydew honey samples after 24 and $48 \mathrm{~h}$ of treatment

\begin{tabular}{|c|c|c|c|c|c|c|}
\hline \multirow{2}{*}{$\begin{array}{l}\text { Cell line/honey } \\
\text { sample }\end{array}$} & \multirow{2}{*}{$t / \mathrm{h}$} & \multirow{2}{*}{$\gamma /(\mathrm{mg} / \mathrm{mL})$} & \multicolumn{4}{|c|}{$N($ cell)/\% } \\
\hline & & & sub-G1 & G1 & $S$ & G2/M \\
\hline \multirow{6}{*}{$\mathrm{BJ} / 2$} & \multirow{3}{*}{24} & Control & $20.1 \pm 1.8$ & $49.1 \pm 0.6$ & $33.9 \pm 1.9$ & $17.2 \pm 2.6$ \\
\hline & & 4.44 & $17.8 \pm 1.2$ & $52.5 \pm 2.7$ & $35.9 \pm 4.1$ & $11.7 \pm 1.3$ \\
\hline & & 22.20 & $(49.4 \pm 5.6)^{*}$ & $(63.8 \pm 0.8)^{*}$ & $(22.9 \pm 0.2)^{*}$ & $(13.4 \pm 0.9)^{*}$ \\
\hline & \multirow{3}{*}{48} & Control & $19.1 \pm 0.4$ & $83.5 \pm 1.3$ & $5.7 \pm 0.2$ & $10.8 \pm 1.4$ \\
\hline & & 4.44 & $19.5 \pm 2.6$ & $82.4 \pm 0.7$ & $(10.1 \pm 0.7)^{*}$ & $7.7 \pm 1.3$ \\
\hline & & 22.20 & $(71.9 \pm 7.6)^{*}$ & $(57.8 \pm 0.5)^{*}$ & $(30.8 \pm 0.6)^{*}$ & $11.5 \pm 1.1$ \\
\hline \multirow{6}{*}{ SW620/3 } & \multirow{3}{*}{24} & Control & $18.0 \pm 1.0$ & $26.9 \pm 3.4$ & $56.6 \pm 3.2$ & $16.6 \pm 0.3$ \\
\hline & & 7.96 & $14.9 \pm 0.2$ & $31.9 \pm 2.1$ & $47.7 \pm 8.2$ & $20.5 \pm 6.2$ \\
\hline & & 39.80 & $(24.3 \pm 4.8)^{*}$ & $(43.5 \pm 1.4)^{*}$ & $(33.2 \pm 5.8)^{*}$ & $23.3 \pm 4.4$ \\
\hline & \multirow{3}{*}{48} & Control & $27.8 \pm 0.1$ & $32.2 \pm 2.1$ & $47.1 \pm 0.1$ & $20.7 \pm 2.3$ \\
\hline & & 7.96 & $27.5 \pm 0.7$ & $39.4 \pm 4.4$ & $46.8 \pm 1.8$ & $13.8 \pm 2.7$ \\
\hline & & 39.80 & $(46.3 \pm 4.6)^{*}$ & $(46.1 \pm 3.9)^{*}$ & $37.6 \pm 7.1$ & $16.4 \pm 3.2$ \\
\hline \multirow{6}{*}{ MCF-7/4 } & \multirow{3}{*}{24} & Control & $39.6 \pm 3.0$ & $41.6 \pm 1.6$ & $36.7 \pm 3.4$ & $21.7 \pm 1.8$ \\
\hline & & 9.94 & $50.6 \pm 5.0$ & $35.8 \pm 1.7$ & $41.6 \pm 1.1$ & $22.6 \pm 0.6$ \\
\hline & & 49.70 & $(63.6 \pm 7.0)^{*}$ & $(29.4 \pm 0.8)^{*}$ & $34.3 \pm 1.6$ & $(36.4 \pm 2.5)^{*}$ \\
\hline & \multirow{3}{*}{48} & Control & $46.1 \pm 3.2$ & $45.9 \pm 3.0$ & $18.0 \pm 1.4$ & $36.2 \pm 4.5$ \\
\hline & & 9.94 & $49.4 \pm 5.8$ & $45.1 \pm 1.9$ & $16.8 \pm 2.4$ & $38.2 \pm 0.5$ \\
\hline & & 49.70 & $(75.9 \pm 4.0)^{*}$ & $36.3 \pm 3.3$ & $(33.1 \pm 4.9)^{*}$ & $30.6 \pm 8.1$ \\
\hline
\end{tabular}

Honey samples were selected according to the most potent $I C_{50}$ value and $5 \cdot I C_{50}$ specific cell line. Values are expressed as mean \pm standard deviation. *statistically significant at $p<0.05$ 
antiproliferative effect. Treatment of human peripheral blood promyelocytic leukaemia cells (HL-60) with Spanish honey revealed that apoptosis plays a central role in the observed antiproliferative effect (54). Jaganathan and Mandal (55) also identified apoptosis as possible molecular mechanism responsible for honey inhibition of colon cancer cell growth. In a similar study (18), it was shown that tualang honey induces apoptosis in human breast cancer cell lines (MCF-7, MDA-MB-231) and cervical cancer cell lines (HeLa), but it was not cytotoxic for normal breast epithelial cell line MCF-10A. Seyhan et al. (53) showed that $2.5 \mu \mathrm{g} / \mathrm{mL}$ of pine honey induces apoptosis in $38.88 \%$ of the MCF-7 cells at 48 h. Moreover, Tsiapara et al. (56) studied the effect of Greek pine and fir honeydew honey extracts on the viability of Ishikawa, MCF-7 and PC-3 cancer cells. They found that pine and fir honey extracts at concentrations $0.2-125 \mu \mathrm{g} / \mathrm{mL}$ did not show any significant effect on the Ishikawa and PC-3 cell viability, but fir honey stimulated the viability of MCF-7 cells. Spilioti et al. (57) examined the ability of honeydew honey from Crete to influence viability of breast cancer (MCF-7) cells and to lower the TNF-a-induced adhesion molecule expression in endothelial cells. Their results showed that honey reduced significantly the viability of MCF-7 cells and the expression of adhesion molecules in endothelial cells. Although our research showed that honey samples have antiproliferative effect on BJ cell line and sample 2 caused considerable increase in the sub-G1 phase, annexin $V$ test on the other hand showed that apoptosis was not the mechanism of observed BJ cell death. It is plausible that honey samples have a different mechanism through which they express their antiproliferative effect on cancer cell lines and normal fibroblast.

Antibacterial properties of honey samples were additionally analysed. The tested bacteria, S. aureus, S. epidermidis (Table 4) and A. baumannii (Table 5), regardless of their antibiotic resistance, were sensitive to all honey samples. Minimum inhibitory concentrations (MIC) against Staphylococccus strains were from 0.0125 to $0.025 \mathrm{~g} / \mathrm{mL}$, while for bactericidal effect (MBC) two times higher concentrations were needed, ranging from 0.025 to $0.05 \mathrm{~g} / \mathrm{mL}$. Concentrations from 0.025 to $0.05 \mathrm{~g} / \mathrm{mL}$ were inhibitory against Acinetobacter strains, while concentrations from 0.05 to $0.1 \mathrm{~g} / \mathrm{mL}$ achieved bactericidal effect. There were no significant differences between antibacterial activity of the tested honey samples against Staphylococcus and Acinetobacter. Interestingly, resistant Acinetobacter strains, including multiresistant strain $A$. baumannii ATCC BAA-1605, were significantly more sensitive to the MIC and $\mathrm{MBC}$ of the tested honey samples than the susceptible strains $(p=0.002)$.

Results of well diffusion tests showed that all tested Staphylococcus strains were more sensitive than Acinetobacter strains to all honey samples with inhibition zones between 13 and $21 \mathrm{~mm}$, while the inhibition zone of Acinetobacter strains varied between 7 and $14 \mathrm{~mm}$ (Fig. 1). There were no significant sensitivity differences between the antibiotic-resistant and susceptible bacterial Staphylococcus and Acinetobacter strains to the tested honey samples.

Table 4. Minimum inhibitory concentration (MIC) and minimum bactericidal concentration (MBC) of fir (Abies alba Mill.) honeydew honey against Staphylococccus aureus and Staphylococcus epidermidis strains

\begin{tabular}{|c|c|c|c|c|c|c|c|c|c|c|c|c|}
\hline \multirow{4}{*}{$\begin{array}{l}\text { Honey } \\
\text { sample }\end{array}$} & \multicolumn{12}{|c|}{ Staphylococcus spp. } \\
\hline & \multicolumn{2}{|c|}{$\begin{array}{c}\text { S. aureus ATCC } \\
25923\end{array}$} & \multicolumn{2}{|c|}{ S. aureus } & \multicolumn{2}{|c|}{ MRSA1 } & \multicolumn{2}{|c|}{ MRSA2 } & \multicolumn{2}{|c|}{ S. epidermidis } & \multicolumn{2}{|c|}{ MRSE } \\
\hline & \multicolumn{12}{|c|}{$\gamma /(\mathrm{g} / \mathrm{mL})$} \\
\hline & MIC & MBC & MIC & MBC & MIC & MBC & MIC & MBC & MIC & MBC & MIC & MBC \\
\hline 1 & 0.025 & 0.05 & 0.025 & 0.05 & 0.025 & 0.05 & 0.0125 & 0.025 & 0.025 & 0.05 & 0.025 & 0.05 \\
\hline 2 & 0.025 & 0.05 & 0.025 & 0.05 & 0.025 & 0.05 & 0.0125 & 0.025 & 0.0125 & 0.025 & 0.0125 & 0.025 \\
\hline 3 & 0.0125 & 0.025 & 0.0125 & 0.025 & 0.025 & 0.05 & 0.0125 & 0.025 & 0.0125 & 0.025 & 0.0125 & 0.025 \\
\hline 4 & 0.025 & 0.05 & 0.025 & 0.05 & 0.025 & 0.05 & 0.0125 & 0.025 & 0.0125 & 0.025 & 0.0125 & 0.025 \\
\hline Vancomycin & $10^{-6}$ & $10^{-6}$ & $5 \cdot 10^{-7}$ & $10^{-6}$ & $10^{-6}$ & $10^{-6}$ & $10^{-6}$ & $10^{-6}$ & $7.5 \cdot 10^{-7}$ & $7.5 \cdot 10^{-7}$ & $2 \cdot 10^{-6}$ & $2 \cdot 10^{-6}$ \\
\hline
\end{tabular}

$\mathrm{MIC} / \mathrm{MBC}=99 \%$ of bacteriostatic and $99 \%$ of bacterial killing effect

Table 5. Minimum inhibitory concentration (MIC) and minimum bactericidal concentration (MBC) of fir (Abies alba Mill.) honeydew honey against different Acinetobacter baumannii strains

\begin{tabular}{|c|c|c|c|c|c|c|c|c|c|c|c|c|}
\hline \multirow{4}{*}{$\begin{array}{l}\text { Honey } \\
\text { sample }\end{array}$} & \multicolumn{12}{|c|}{ Acinetobacter baumannii } \\
\hline & \multicolumn{2}{|c|}{ ATCC BAA-1605 } & \multicolumn{2}{|c|}{ ATCC 19606} & \multicolumn{2}{|c|}{56781} & \multicolumn{2}{|c|}{54531} & \multicolumn{2}{|c|}{53154} & \multicolumn{2}{|c|}{771} \\
\hline & \multicolumn{12}{|c|}{$\gamma /(\mathrm{g} / \mathrm{mL})$} \\
\hline & MIC & MBC & MIC & MBC & MIC & MBC & MIC & MBC & MIC & MBC & MIC & MBC \\
\hline 1 & 0.05 & 0.1 & 0.05 & 0.1 & 0.05 & 0.1 & 0.05 & 0.1 & 0.025 & 0.05 & 0.05 & 0.1 \\
\hline 2 & 0.025 & 0.05 & 0.05 & 0.1 & 0.025 & 0.05 & 0.05 & 0.1 & 0.025 & 0.05 & 0.05 & 0.1 \\
\hline 3 & 0.025 & 0.05 & 0.05 & 0.1 & 0.025 & 0.05 & 0.025 & 0.05 & 0.025 & 0.05 & 0.05 & 0.1 \\
\hline 4 & 0.05 & 0.1 & 0.05 & 0.1 & 0.025 & 0.05 & 0.025 & 0.05 & 0.05 & 0.1 & 0.05 & 0.1 \\
\hline Vancomycin & $>3.2 \cdot 10^{-5}$ & $>3.2 \cdot 10^{-5}$ & $2.5 \cdot 10^{-7}$ & $2.5 \cdot 10^{-7}$ & $>3.2 \cdot 10^{-5}$ & $>3.2 \cdot 10^{-5}$ & $>3.2 \cdot 10^{-5}$ & $>3.2 \cdot 10^{-5}$ & $>3.2 \cdot 10^{-5}$ & $>3.2 \cdot 10^{-5}$ & $2.5 \cdot 10^{-7}$ & $2.5 \cdot 10^{-7}$ \\
\hline
\end{tabular}

$\mathrm{MIC} / \mathrm{MBC}=99 \%$ of bacteriostatic and $99 \%$ of bacterial killing effect 

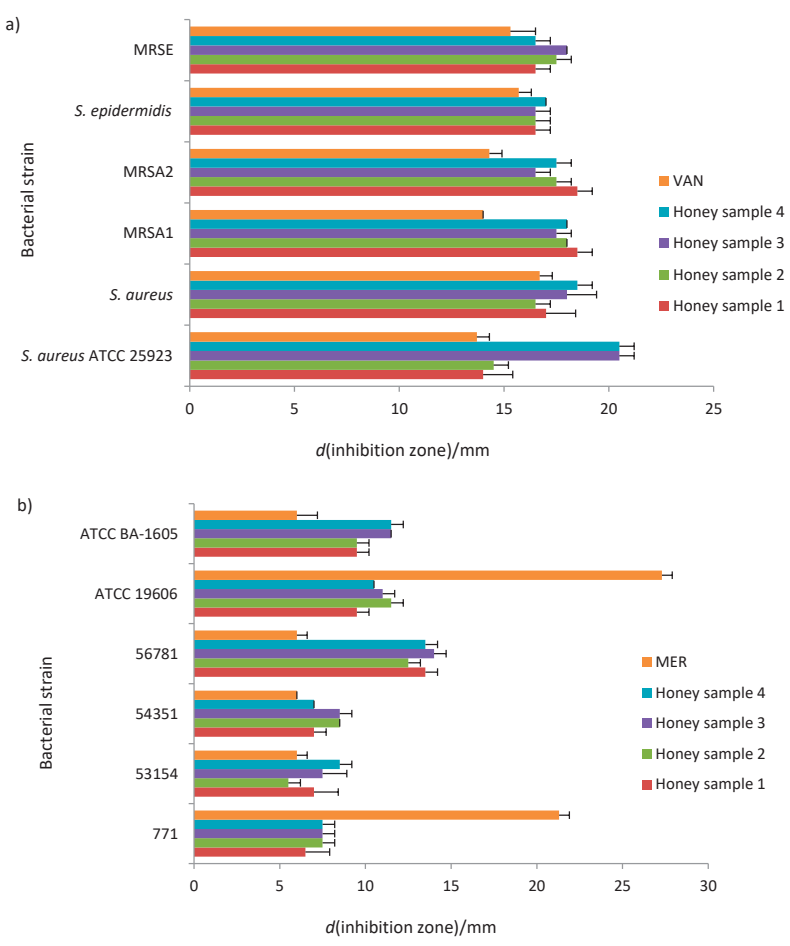

Fig. 1. Inhibition zone after application of fir (Abies alba Mill.) honeydew honey samples (1-4), and vancomycin (VAN) and meropenem (MER) as positive controls against: a) Staphylococccus aureus and Staphylococcus epidermidis strains, and b) Acinetobacter baumannii strains. Values are expressed as mean \pm standard deviation

An interesting biological effect of honeydew honey is related to antibacterial properties as well. Previous reports indicate that, generally, all honey samples have a certain antibacterial potential. For instance, Majtan et al. (10) investigated antibacterial effect of Slovak honeydew honey against 20 nosocomial multidrug-resistant Stenotrophomonas maltophilia isolates from cancer patients and they found strong antibacterial activity of honey, and concluded that it could be used as alternative therapeutic agent against bacterial infections. Pérez Martin et al. (43) analysed the capacity of Spanish honeydew honey to inhibit Micrococcus luteus and S. aureus. Their results showed that a high percentage (77\%) of the honey samples inhibited the $M$. luteus growth, while only $41 \%$ inhibition of S. aureus was observed. Sagdic et al. (58) evaluated the antimicrobial activity of Turkish honeydew honey using 12 bacteria and two yeasts. They found that the honey samples showed the highest antimicrobial activity against Escherichia coli O-157:H7, S. aureus and Listeria monocytogenes. On the contrary, Bacillus subtilis was the most resistant microorganism. Moreover, Adams et al. (59) report on the antibacterial activity of manuka honey which originates directly from the methylglyoxal. On the other hand, antibacterial bee defensin-1 has very recently been identified in honey-based product Revamil $^{\oplus}$ and it contributes to the antibacterial activity of medical-grade honey (60). It remains to be established whether methylglyoxal and antibacterial bee peptide are also present in other natural types of honey. Bactericidal activity of honey samples was tested against two Staphylococccus strains and multidrug-resistant A. baumannii (an aerobic, Gram(-) coccobacillus) isolates. All tested samples showed both cell growth inhibitory and bactericidal properties in a concentration-dependent manner. This characteristic of fir honeydew honey is of special importance if we take into consideration that multidrug resistance in nosocomial pathogens is continually evolving and represents an alarming problem in health care units. The scientific community generally agrees that novel or the existing reusable antibacterial agents are urgently needed for treatment of infections caused by multidrug-resistant $A$. baumannii, which has become an emerging problematic pathogen over the past 15 years. A. baumannii is resistant to almost all conventional antibiotics by a wide range of mechanisms and can survive for prolonged periods on the surfaces of instruments in hospital settings (61). Fir honeydew honey has a potential as a natural candidate that might find application in the fight against $A$. baumannii infections. Indeed, to our knowledge this is the first report of honeydew honey antibacterial effect on A. baumannii isolates. Tested samples have also showed antibacterial properties against Staphylococcus strains. S. aureus is a major cause of wound infection throughout the world. These antibacterial properties might be used in different clinical situations. For example, manuka honey is used in modern wound healing formulations and has been shown to eradicate methicillin-resistant S. aureus (MRSA) from wounds. In vitro clinical isolates of methicillin-susceptible and methicillin-resistant staphylococci were shown to be equally susceptible to manuka honey (62).

\section{Antioxidant potential and kinetic analysis of fir honeydew honey samples}

Radical scavenging assay was used to evaluate antioxidant potential of honeydew honey and determine constants of the kinetic process as well to explain the mechanisms controlling the antioxidant activity. Experimental data were fitted to seven mathematical models, three monophasic (Eqs. 3-5) and four biphasic (Eqs. 6-9). The kinetics of DPPH disappearance in honey samples is shown in Fig. 2, where experimental data for remaining $\mathrm{DPPH}^{\circ}$ are plotted against the reaction time and presented together with the curves simulated by the best fit of all mathematical models. As can be seen, the kinetics of DPPH disappearance can be considered to be the sum of two consecutive phases. At the beginning of the reaction, rapid exponential decay of DPPH' is observable (Fig. 2), while later changes were slow and proportional to the time. The time of the rapid phase was determined by the first-order discontinuous biphasic model (Eq. 8) and also confirmed graphically according to the slope of the DPPH disappearance curve.

The longest time of rapid reaction phase was obtained with honey sample 3 (2.5 min; Table 6), and the shortest with samples 1 and 4 (1.5 $\mathrm{min})$. At the end of the rapid reaction phase, samples 1 and 4 depleted approx. $8.60 \%$ of the initial $\mathrm{DPPH}^{\circ}$ amount, while this percentage was evidently higher 


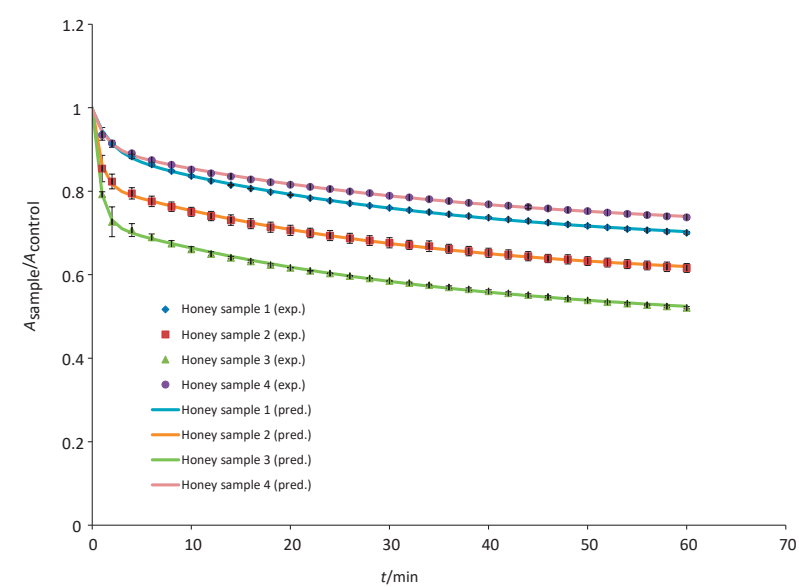

Fig. 2. Experimental data and theoretical curves from the first-order double exponential model of DPPH disappearance in fir (Abies alba Mill.) honeydew honey samples (1-4). Values are expressed as mean \pm standard deviation. exp.=experimental, pred.=predicted (first-order double exponential model)

with sample 3 (28.49\%). Likewise, at the end of the reaction, the overall depleted DPPH' amount was considerably lower $(27.99 \%)$ in samples 1 and 4 than in sample 3 (47.74 \%). Although the time of the first phase of $\mathrm{DPPH}^{\cdot}$ disappearance and antioxidant activity of samples 1 and 4 were almost identical, differences in their antioxidant activity at the end of reaction can be found (Table 6). Wilczyńska (63) found lower (23.81 \%) values of DPPH ${ }^{\prime}$ inhibition by Polish nectar and honeydew honey samples, but higher inhibition values (from 72.54 to $83.51 \%)$ by honeydew honey than in our study. Socha et al. (17) found 34.6\% DPPH inhibition by Polish nectar and honeydew honey types, but lower inhibition values of honeydew honey $(20.7 \%)$ than in the previously mentioned study. Chis et al. (64) found that Polish and Romanian honeydew honey samples inhibited 19.21 and $20.38 \% \mathrm{DPPH}^{\circ}$ radical, respectively. Pérez Martin et al. (43) determined high values of DPPH inhibition (60.8\%) of Spanish honeydew honey and Sagdic et al. (58) of Turkish honeydew honey (62.6\%). After considering the statistical indices ( $\mathrm{R}^{2}$, SRMSE and $\chi^{2}$ error) and comparing the goodness of fit of the tested mathematical models to the experimental values, we concluded that the biphasic kinetic models (Weibull, first-order double exponential and Gustafson and Holden model) describe more satisfactorily the DPPH disappearance than monophasic models, which is confirmed by the high coefficients of determination and low error values $\left(R^{2}>0.9996\right.$, SRMSE $=0.0024-0.0189 ; \chi^{2}$ error $\left.=0.22-1.69\right)$. First-order discontinuous biphasic model was also tested, but it gave slightly lower coefficients of determination and higher error values. Among the tested models, the lowest errors (SRMSE $=0.0024-0.0041$ and $\chi^{2}$ error $=0.22-0.37$; Table 6) and the highest $R^{2}$ values $\left(R^{2}=0.9999\right)$ were obtained with the first-order double exponential model, followed by the Weibull distribution model, the Gustafson and Holden model and first-order discontinuous model. The values for antiradical capacity (TEAC value) ranged from 0.52 (sample 4) to 1.01 (sample 3) mmol TEAC per kg honey (Table 6).

Furthermore, in order to examine the possible impact of rate constants on the radical scavenging capacity of the honey samples, Kendall's Tau nonparametric analysis was done. Correlation analysis between TEAC values and rate constants obtained from the first-order double exponential model showed that the first phase of DPPH disappearance in the experimental honey samples was positively influenced by $k_{1}$ (0.67), while the relation between TEAC and $k_{2}$ was also positive (0.33), but it was insignificant at $\mathrm{p}<0.05$ level. In addition to the nonparametric test, multiple linear regression analysis was used, which simultaneously compares antiradical activity and rate constants $\left(k_{1}\right.$ and $\left.k_{2}\right)$ leading to a linear predictive model for TEAC values. This analysis resulted in the following correlations for TEAC:

$$
\text { TEAC }=0.0955 \cdot k_{1}+0.0019 \cdot k_{2}+0.0038\left(R^{2}=0.7598\right)
$$

Nonparametric regression analysis showed that two groups of antioxidants affected DPPH' disappearance, but the multiple linear regression equation suggested that the antioxidants involved in the first phase of reaction predominantly influenced DPPH disappearance in the experimental honey samples.

In this study we obtained similar results to those from our previous experiments including the analysis of kinetic reaction between $\mathrm{DPPH}^{\circ}$ and antioxidants present in honey samples. We found that measured DPPH disappearance in our in vitro model may be best described by biphasic kinetic models. All previous observations about biphasic DPPH disappearance indicate that the scavenging process might be governed

Table 6. Results of antiradical activity (DPPH' assay), time of the first phase of antiradical activity reaction, percentages of DPPH depleted in the first phase and at the end of reaction, and kinetic parameters of $\mathrm{DPPH}^{\circ}$ disappearance estimated by the first-order double exponential model for the fir (Abies alba Mill.) honeydew honey samples

\begin{tabular}{|c|c|c|c|c|c|c|c|c|c|}
\hline \multirow{2}{*}{ Honey sample } & \multirow{2}{*}{$\begin{array}{c}(\mathrm{n}(\mathrm{TEAC}) / \\
m(\text { honey))/ } \\
(\mathrm{mmol} / \mathrm{kg})\end{array}$} & \multirow{2}{*}{$t_{1} / \min$} & \multirow{2}{*}{$\mathrm{DPPH}^{\mathrm{a}} / \%$} & \multirow{2}{*}{$\mathrm{DPPH}^{\mathrm{b}} \%$} & \multicolumn{5}{|c|}{ First-order double exponential model } \\
\hline & & & & & $k_{1} / \min ^{-1}$ & $k_{2} / \min ^{-1}$ & $\mathrm{R}^{2}$ & SRMSE & $x^{2}$ error \\
\hline 1 & $0.63 \pm 0.01$ & 1.5 & 8.65 & 29.83 & 0.5808 & 0.0292 & 0.9999 & 0.0025 & 0.22 \\
\hline 2 & $0.80 \pm 0.02$ & 2.0 & 17.66 & 38.22 & 1.2523 & 0.0311 & 0.9999 & 0.0038 & 0.35 \\
\hline 3 & $1.01 \pm 0.01$ & 2.5 & 28.49 & 47.74 & 1.3094 & 0.0286 & 0.9999 & 0.0041 & 0.37 \\
\hline 4 & $0.52 \pm 0.01$ & 1.5 & 8.50 & 26.14 & 0.7399 & 0.0280 & 0.9999 & 0.0024 & 0.22 \\
\hline
\end{tabular}

$t_{1}=$ time of the first phase of DPPH disappearance, $k_{1}$ and $k_{2}=$ kinetic rate constants in first-order double exponential model, $\mathrm{R}^{2}=$ determination coefficient, SRMSE=scaled root mean squared error, $\mathrm{X}^{2}$ error=error of chi-square test, ${ }^{\mathrm{a}}$ percentage of DPPH ${ }^{\circ}$ depleted in the first phase of reaction, bpercentage of DPPH' depleted at the end of the reaction 
by two different reaction mechanisms, which is consistent with our results as well. For example, Espin et al. (65) studied DPPH' disappearance in the presence of different kinds of oil and found that experimental data were well fitted by a double exponential equation. Similar biphasic behaviour of DPPH disappearance was found in the study of antiradical activity of citrus juices (66) and pumpkin seed oil (67). Broznić et al. (67) attributed the observed DPPH' behaviour to the presence of antioxidant compounds in the food matrix that have functional groups capable of both fast and slow atom hydrogen donation. Biphasic DPPH' behaviour was also observed in our previous study of biological effects of Satureja montana L. honey (26), where DPPH' initially exerted a fast radical loss rate slowing down after $3 \mathrm{~min}$. Likewise, research done by Terpinc et al. (68) on the kinetics of DPPH' disappearance in rosemary extracts also showed a biphasic DPPH pattern, in which the DPPH' initially had a rapid rate of loss and was slower after 10 min. Thus, compounds exhibiting rapid and slow antiradical kinetics possess different radical inhibition abilities and they react at different rates with radicals in a two-phase reaction. The overall reaction rate is therefore characterised by two rate constants, $k_{1}$ and $k_{2}$, which represent the rate of fast and slow DPPH disappearance. Assuming that during their action all present antioxidants react with the $\mathrm{DPPH}^{\text {, }}$, constants $k_{1}$ and $k_{2}$ can represent the rate of antioxidant disappearance. Therefore, it can be concluded that the amount of disappeared DPPH ${ }^{*}$ was equal to the capacity of the fast and slow kinetics components to scavenge radicals. The observed range of antiradical capacity, expressed as Trolox equivalents, of honey samples in our study, from 0.52 (sample 4) to 1.01 (sample 3) $\mathrm{mmol} / \mathrm{kg}$ honey, is similar to asphodel honey (Asphodelus microcarpus Salzm. et Viv., 0.7 mmol/kg) (69), Dalmatian sage honey $(0.2-0.9 \mathrm{mmol} / \mathrm{kg})(70)$, heather honey $(0.6$ $\mathrm{mmol} / \mathrm{kg}$ ) (71) and Polish fir honeydew honey $(1.1 \mathrm{mmol} / \mathrm{kg}$ ) (37). However, in the literature higher values were found for the Salix spp. honeydew honey collected in different areas of central-east Croatia (3.0 mmol/kg) (48), Serbian pine honeydew honey $(5.06 \mathrm{mmol} / \mathrm{kg}$ ) (72) and oak honeydew honey, (4.5 and $5.1 \mathrm{mmol} / \mathrm{kg}$ ) (73). The reason for this difference in TEAC values was noticeably lower amount of honeydew elements in the sample sediments of these honeydew honey compared to our samples.

\section{CONCLUSION}

In conclusion, the 'in vitro assay' used in the present study shows that honeydew honey has a strong antitumour and antibacterial activity, as well as a high antiradical potential. It has a remarkable capacity to inhibit tumour cell growth in significantly lower concentrations than other honey samples described in the literature, attributable to the induction of apoptosis, as well as antibacterial properties against multidrug-resistant bacteria. All these valuable biological properties point to this product as a worthy source for development of medical compounds, and further detailed characterisation and mechanistic studies are required.

\section{ACKNOWLEDGEMENTS}

This work was supported by the project of the Croatian Science Foundation'High throughput analytical platforms for Adriatic-brand food quality and authenticity' and University of Rijeka research grants 13.11.1.1.11, 13.11.1.2.01 and 13.06.2.2.60. We greatly acknowledge the access to the equipment in possession of University of Rijeka within the project RISK 'Development of University of Rijeka campus laboratory research infrastructure', financed by European Regional Development Fund (ERDF). Authors extend thanks to Mr Damir Zanoškar (Gorski d.o.o) for kindly providing honey samples, and to Andreja Zubković and Goranka Crnković for their kind assistance.

\section{REFERENCES}

1. Bashkaran K, Zunaina E, Bakiah S, Sulaiman SA, Sirajudeen KNS, Naik V. Anti-inflammatory and antioxidant effects of Tualang honey in alkali injury on the eyes of rabbits: Experimental animal study. BMC Complem Altern M. 2011;11(90). https://doi.org/10.1186/1472-6882-11-90

2. Chua LS, Rahaman NLA, Adnan NA, Tan TTE. Antioxidant activity of three honey samples in relation with their biochemical components. J Anal Methods Chem. 2013;2013:Article ID: 313798.

https://doi.org/10.1155/2013/313798

3. Samarghandian S, Afshari JT, Davoodi S. Honey induces apoptosis in renal cell carcinoma. Pharmacogn Mag. 2011; 7(25):46-52.

https://doi.org/10.4103/0973-1296.75901

4. Sufya N, Matar N, Kaddura R, Zorgani A. Evaluation of bactericidal activity of Hannon honey on slowly growing bacteria in the chemostat. Drug Healthc Patient Saf. 2014;2014(6): 139-144.

https://doi.org/10.2147/DHPS.S66496

5. Watanabe K, Rahmasari R, Matsunaga A, Haruyama T, Kobayashi N. Anti-influenza viral effects of honey in vitro: Potent high activity of manuka honey. Arch Med Res. 2014; 45(5):359-65.

https://doi.org/10.1016/j.arcmed.2014.05.006

6. Estevinho ML, Afonso SE, Feás X. Antifungal effect of lavender honey against Candida albicans, Candida krusei and Cryptococcus neoformans. J Food Sci Technol. 2011;48(5): 640-3.

https://doi.org/10.1007/s13197-011-0243-1

7. Feás X, Estevinho ML. A survey of the in vitro antifungal activity of heather (Erica sp.) organic honey. J Med Food. 2011; 14(10):1284-8.

https://doi.org/10.1089/jmf.2010.0211

8. Feás X, Iglesias A, Rodrigues S, Estevinho LM. Effect of Erica sp. honey against microorganisms of clinical importance: Study of the factors underlying this biological activity. Molecules. 2013;18(4):4233-46.

https://doi.org/10.3390/molecules18044233 
9. Pita-Calvo C, Vásquez M. Honeydew honeys: A review on the characterization and authentication of botanical and geographical origins. J Agric Food Chem. 2018;66(11):2523-37. https://doi.org/10.1021/acs.jafc.7b05807

10. Majtan J, Majtanova L, Bohova J, Majtan V. Honeydew honey as a potent antibacterial agent in eradication of multi-drug resistant Stenotrophomonas maltophilia isolates from cancer patients. Phytother Res. 2011;25(4):584-7.

https://doi.org/10.1002/ptr.3304

11. Karabagias IK, Badeka A, Kontakos S, Karabournioti S, Kontominas MG. Characterisation and classification of Greek pine honeys according to their geographical origin based on volatiles, physicochemical parameters and chemometrics. Food Chem. 2014;146:548-57.

https://doi.org/10.1016/j.foodchem.2013.09.105

12. Ajibola A, Chamunorwa JP, Erlwanger KH. Nutraceutical values of natural honey and its contribution to human health and wealth. Nutr Metab. 2012;9(61):1-12.

https://doi.org/10.1186/1743-7075-9-61

13. Council of the European Union. Council Directive 2001/110/ EC of 20 December 2001 relating to honey. Off J Eur Commun. 2002;L10:47-52.

14. Lušić D, Nekić D, Ožanić M, Majetić V, Malenica Staver M. Selected indicators of quality of thick honey from Gorski Kotar 2006 and 2007. Proceedings of the 44th Croatian and 4th International Symposium on Agriculture; 2009 February 16-20, Opatija, Croatia: Josip Juraj Strossmayer University, Agriculture Faculty in Osijek; 2009. pp. 696-701.

15. Lušić D, Koprivnjak O, Ćurić D, Sabatini AG, Conte LS. Volatile profile of Croatian lime tree (Tilia sp.), fir honeydew (Abies alba) and sage (Salvia officinalis) honey. Food Technol Biotechnol. 2007;45(2):156-65.

16. Moniruzzaman M, An CY, Rao PV, Hawlader MNI, Azlan SABM, Sulaiman SA, Gan SH. Identification of phenolic acids and flavonoids in monofloral honey from Bangladesh by high performance liquid chromatography: Determination of antioxidant capacity. BioMed Res Int. 2014;2014:Article ID 737490. https://doi.org/10.1155/2014/737490

17. Socha R, Juszczak L, Pietrzyk S, Gałkowska D, Fortuna T, Witczak T. Phenolic profile and antioxidant properties of Polish honeys. Int J Food Sci Tehnol. 2011;46(3):528-34. https://doi.org/10.1111/j.1365-2621.2010.02517.x

18. Fauzi AN, Norazmi MN, Yaacob NS. Tualang honey induces apoptosis and disrupts the mitochondrial membrane potential of human breast and cervical cancer cell lines. Food Chem Toxicol. 2011;49(4):871-8. https://doi.org/10.1016/j.fct.2010.12.010

19. Vela L, de Lorenzo C, Pérez RA. Antioxidant capacity of Spanish honeys and its correlation with polyphenol content and other physicochemical properties. J Sci Food Agric. 2007;87(6):1069-75.

https://doi.org/10.1002/jsfa.2813
20. Ferreira ICFR, Aires E, Barreira JCM, Estevinho LM. Antioxidant activity of Portuguese honey samples: Different contributions of the entire honey and phenolic extract. Food Chem. 2009;114(4):1438-43.

https://doi.org/10.1016/j.foodchem.2008.11.028

21. Majtan J, Bohova J, Garcia-Villalba R, Tomas-Barberan FA, Madakova Z, Majtan T, et al. Fir honeydew honey flavonoids inhibit TNF-a-induced MMP-9 expression in human keratinocytes: A new action of honey in wound healing. Arch Dermatol Res. 2013;305(7):619-27.

https://doi.org/10.1007/s00403-013-1385-y

22. Louveaux J, Maurizio A, Vorwohl G. Methods of melissopalynology. Bee World. 1978; 59(4):139-57.

https://doi.org/10.1080/0005772X.1978.11097714

23. Bogdanov S. Harmonised methods of the International Honey Commission. Bremen, Germany: International Honey Commission; 2009. Available from: http://www.ihc-platform.net/ihcmethods2009.pdf.

24. Bogdanov S, Lüllmann C, Martin P, von der Ohe W, Russmann $\mathrm{H}$, Vorwohl $\mathrm{G}$, et al. Honey quality and international regulatory standards: Review by the International Honey Commission. Bee World. 2015;80(2):61-9. https://doi.org/10.1080/0005772X.1999.11099428

25. Gazivoda T, Plevnik M, Plavec J, Kraljević S, Kralj M, Pavelić K, et al. The novel pyrimidine and purine derivatives of $\mathrm{I}$-ascorbic acid: synthesis, one- and two-dimensional ${ }^{1} \mathrm{H}$ and ${ }^{13} \mathrm{C}$ NMR study, cytostatic and antiviral evaluation. Bioorg Med Chem. 2005;13(1):131-9. https://doi.org/10.1016/j.bmc.2004.09.052

26. Malenica Staver M, Ratkaj I, Broznić D, Jerković I, Marijanović Z, Željezić D, Kraljević Pavelić S. Bioactivity of Satureja montana L. honey extracts and their profile screening. RSC Adv. 2014;4:47329-40.

https://doi.org/10.1039/C4RA08368G

27. Breakpoint tables for interpretation of MICs and zone diameters, v. 7.1. The European Committee on Antimicrobial Susceptibility Testing (EUCAST); 2017. Available from: http://www.eucast.org/clinical_breakpoints/.

28. Piljac-Žegarac J, Stipčević T, Belščak A. Antioxidant properties and phenolic content of different floral origin honeys. JAAS. 2009;1(2):43-50. https://doi.org/10.3896/IBRA.4.01.2.04

29. Wolfram Mathematica ${ }^{\circledR}$, v. 9.0, Wolfram, Champaign, IL, USA; 2012. Available from: http://www.wolfram.com/mathematica/.

30. STATISTICA, v. 13.0, StatSoft, Inc, Tulsa, OK, USA; 2017. Available from: http://www.statsoft.com.

31. Von Der Ohe W, Persano Odo L, Piana ML, Morlot M, Martin P. Harmonized medthods of melissopalinology. Apidologie. 2004;35(Suppl. 1):S18-25. https://doi.org/10.1051/apido:2004050

32. Estevinho LM, Feás X, Seijas JA, Vásquez-Tato MP. Organic honey from Trás-Os-Montes region (Portugal): Chemical, 
palynological, microbiological and bioactive compounds characterization. Food Chem Toxicol. 2012;50(2):258-64.

https://doi.org/10.1016/j.fct.2011.10.034

33. Feás X, Pires J, Iglesias A, Estevinho ML. Characterization of artisanal honey produced on the northwest of Portugal by melissopalynological and physico-chemical data. Food Chem Toxicol. 2010;48(12):3462-70.

https://doi.org/10.1016/j.fct.2010.09.024

34. Bertoncelj J, Golob T, Kropf U, Korošec M. Characterisation of Slovenian honeys on the basis of sensory and physicochemical analysis with a chemometric approach. Int J Food Sci Tehnol. 2011;46(8):1661-71.

https://doi.org/10.1111/j.1365-2621.2011.02664.x

35. Kropf U, Jamnik M, Bertoncelj J, Golob T. Linear regression model of the ash mass fraction and electrical conductivity for Slovenian honey. Food Technol Biotechnol. 2008;46(3): 335-40.

36. Malika N, Mohamed F, Chakib EA. Microbiological and physico-chemical properties of Moroccan honey. Int J Agric Biol. 2005;7(5):773-6.

37. Kuś PM, Jerković I, Marijanović Z, Tuberoso CIG. Screening of Polish fir honeydew honey using GC/MS, HPLC-DAD and physical-chemical parameters: Benzene derivatives and terpenes as chemical markers. Chem Biodivers. 2017;14(9): e1700179.

https://doi.org/10.1002/cbdv.201700179

38. Rybak-Chmielewska H, Szczęsna T, Waś E, Jaśkiewicz K, Teper D. Characteristics of Polish unifloral honeys IV. Honeydew honey, mainly Abies alba L. J Apic Sci. 2013;57(1):51-9. https://doi.org/10.2478/jas-2013-0006

39. Gomes T, Feás X, Iglesias A, Estevinho LM. Study of organic honey from the northeast of Portugal. Molecules. 2011; 16(7):5374-86.

https://doi.org/10.3390/molecules16075374

40. Pires J, Estevinho ML, Feás X, Cantalapiedra J, Iglesias A. Pollen spectrum and physico-chemical attributes of heather (Erica sp.) honeys of north Portugal. J Sci Food Agric. 2009; 89(11);1862-70.

https://doi.org/10.1002/jsfa.3663

41. Feás X, Pires J, Estevinho ML, Iglesias A, Pinto de Araujo JP. Palynological and physicochemical data characterisation of honeys produced in the Entre-Douro e Minho region of Portugal. Int J Food Sci Technol. 2010;45(6):1255-62. https://doi.org/10.1111/j.1365-2621.2010.02268.x

42. Iglesias A, Feás $X$, Rodrigues $S$, Seijas JA, Vásquez-Tato MP, Dias LG, Estevinho LM. Comprehensive study of honey with protected denomination of origin and contribution to the enhancement of legal specifications. Molecules. 2012; 17(7):8561-77.

https://doi.org/10.3390/molecules17078561

43. Pérez Martin RA, Hortigüela LV, Lozano PL, Cortina MDR, Carretero CL. In vitro antioxidant and antimicrobial activities of Spanish honeys. Int J Food Prop. 2008;11(4):727-37.

https://doi.org/10.1080/10942910701586257

44. Persano Oddo L, Piro R. Main European unifloral honeys: Descriptive sheets. Apidologie. 2004;35(Suppl. 1):S38-81. https://doi.org/10.1051/apido:2004049

45. Filipi J, Brajković J, Dražić M, Bubalo D, Kezić N. Multifloral honey from Gacka region. J Cent Eur Agric. 2012;13(4):868-82. https://doi.org/10.5513/JCEA01/13.4.1142

46. Primorac Lj, Angelkov B, Mandić ML, Kenjerić D, Nedeljko M, Flanjak I, et al. Comparison of the Croatian and Macedonian honeydew honey. J Cent Eur Agric. 2009;10(3):263-70.

47. Vanhanen LP, Emmertz A, Savage GP. Mineral analysis of monofloral New Zealand honey. Food Chem. 2011;128(1):236-40. https://doi.org/10.1016/j.foodchem.2011.02.064

48. Tuberoso CIG, Jerkovic I, Bifulco E, Marijanović Z. Biodiversity of Salix spp. honeydew and nectar honeys determined by RP-HPLC and evaluation of their antioxidant capacity. Chem Biodivers. 2011;8(5):872-9.

https://doi.org/10.1002/cbdv.201000359

49. Moniruzzaman M, Chowdhury MAZ, Rahman MA, Sulaiman SA, Gan SH. Determination of mineral, trace element, and pesticide levels in honey samples originating from different regions of Malaysia compared to manuka honey. BioMed Res Int. 2014;2014:Article ID 359890.

https://doi.org/10.1155/2014/359890

50. Terrab A, Recamales AF, Gonzalez-Miret ML, Heredia FJ. Contribution to the study of avocado honeys by their mineral contents using inductively coupled plasma optical emission spectrometry. Food Chem. 2005;92(2):305-9.

https://doi.org/10.1016/j.foodchem.2004.07.033

51. Wen CTP, Hussein SZ, Abdullah S, Karim NA, Makpol S, Yusof YAM. Gelam and nenas honeys inhibit proliferation of HT 29 colon cancer cells by inducing DNA damage and apoptosis while suppressing inflammation. Asian Pac J Cancer Prev. 2012;13(4):1605-10.

https://doi.org/10.7314/APJCP.2012.13.4.1605

52. Hakim L, Alias E, Makpol S, WZ Ngah, Morad NA, Yusof YA. Gelam honey and ginger potentiate the anti cancer effect of 5-FU against HCT 116 colorectal cancer cells. Asian Pac J Cancer Prev. 2014;15(11):4651-7. https://doi.org/10.7314/APJCP.2014.15.11.4651

53. Seyhan MF, Yılmaz E, Timirci-Kahraman Ö, Saygılı N, Kisakesen HI, Eronat AP, et al. Anatolian honey is not only sweet but can also protect from breast cancer: Elixir for women from Artemis to present. IUBMB Life. 2017;69(9):677-88. https://doi.org/10.1002/iub.1652

54. Morales P, Haza Al. Antiproliferative and apoptotic effects of Spanish honeys. Pharmacogn Mag. 2013;9(35):231-7. https://doi.org/10.4103/0973-1296.113276

55. Jaganathan SK, Mandal M. Involvement of non-protein thiols, mitochondrial dysfunction, reactive oxygen species 
and p53 in honey-induced apoptosis. Invest New Drugs. 2010;28(5):624-33.

https://doi.org/10.1007/s10637-009-9302-0

56. Tsiapara AV, Jaakkola M, Chinou I, Graikou K, Tolonen T, Virtanen V, Moutsatsou P. Bioactivity of Greek honey extracts on breast cancer (MCF-7), prostate cancer (PC-3) and endometrial cancer (Ishikawa) cells: Profile analysis of extracts. Food Chem. 2009;116(3):702-8.

https://doi.org/10.1016/j.foodchem.2009.03.024

57. Spilioti E, Jaakkola M, Tolonen T, Lipponen M, Virtanen V, Chinou l, et al. Phenolic acid composition, antiatherogenic and anticancer potential of honeys derived from various regions in Greece. PloS ONE. 2014;9(4):e94860.

https://doi.org/10.1371/journal.pone.0094860

58. Sagdic O, Silici S, Ekici L. Evaluation of the Phenolic Content, Antiradical, Antioxidant, and Antimicrobial Activity of Different Floral Sources of Honey. Int J Food Prop. 2013;16: 658-66.

https://doi.org/10.1080/10942912.2011.561463

59. Adams CJ, Manley-Harris M, Molan PC. The origin of methylglyoxal in New Zealand manuka (Leptospermum scoparium) honey. Carbohydr Res. 2009;344(8):1050-3. https://doi.org/10.1016/j.carres.2009.03.020

60. Kwakman PHS, te Velde AA, de Boer L, VandenbrouckeGrauls CMJE, Zaat SAJ. Two major medicinal honeys have different mechanisms of bactericidal activity. PloS ONE. 2011;6(3):e17709.

https://doi.org/10.1371/journal.pone.0017709

61. Peleg AY, Seifert H, Paterson DL. Acinetobacter baumannii: Emergence of a successful pathogen. Clin Microbiol Rev. 2008;21(3):538-82.

https://doi.org/10.1128/CMR.00058-07

62. Jenkins R, Burton N, Cooper R. Manuka honey inhibits cell division in methicillin-resistant Staphylococcus aureus. J Antimicrob Chemother. 2011;66(11):2536-42.

https://doi.org/10.1093/jac/dkr340

63. Wilczyńska A. Phenolic content and antioxidant activity of different types of Polish honey - A short report. Pol J Food Nutr Sci. 2010;60(4):309-13.

64. Chis AM, Purcarea C, Dzugan M, Teusdea A. Coparative antioxidant content and antioxidant activity of selected Romanian and Polish honeydew honey. Rev Chim (Bucharest). 2016;67(2):214-8.

65. Espin JC, Soler-Rivas C, Wichers HJ. Characterization of the total free radical scavenger capacity of vegetable oils and oil fractions using 2,2-diphenyl-1-picrylhydrazyl radical. J Agr Food Chem. 2000;48(3):648-56.

https://doi.org/10.1021/jf9908188

66. Sendra JM, Sentandreu E, Navarro JL. Kinetic model for the antiradical activity of the isolated $p$-catechol group in flavanone type structures using the free stable radical 2,2-diphenyl-1-picrylhydrazyl as the antiradical probe. J Agric Food Chem. 2007;55(14):5512-22. https://doi.org/10.1021/jf070689s

67. Broznić $D$, Čanadi Jurešić G, Milin Č. Involvement of $a-, \gamma^{-}$ and $\delta$-tocopherol isomers from pumpkin (Cucurbita pepo L.) seed oil or oil mixtures in the biphasic DDPH disappearance kinetics. Food Technol Biotechnol. 2016;54(2):200-10. https://doi.org/10.17113/ftb.54.02.16.4063

68. Terpinc P, Bezjak M, Abramovič H. A kinetic model for evaluation of the antioxidant activity of several rosemary extracts. Food Chem. 2009;115(2):740-4.

https://doi.org/10.1016/j.foodchem.2008.12.033

69. Tuberoso CIG, Bifulco E, Jerković I, Caboni P, Cabras P, Floris I. Methyl syringate: A chemical marker of asphodel (Asphodelus microcarpus Salzm. et Viv.) monofloral honey. J Agric Food Chem. 2009; 57(9);3895-900. https://doi.org/10.1021/jf803991j

70. Tuberoso CIG, Jerković I, Bifulco E, Marijanovic Z, Congiu F, Bubalo D. Riboflavin and lumichrome in Dalmatian sage honey and other unifloral honeys determined by LC-DAD technique. Food Chem. 2012;135(3):1985-90. https://doi.org/10.1016/j.foodchem.2012.06.096

71. Kuś PM, Congiu F, Teper D, Sroka Z, Jerković I, Tuberoso CIG. Antioxidant activity, color characteristics, total phenol content and general HPLC fingerprints of six Polish unifloral honey types. LWT - Food Sci Technol. 2014;55(1):124-30. https://doi.org/10.1016/j.lwt.2013.09.016

72. Gorjanović SŽ, Alvarez-Suarez JM, Novaković MM, Pastor FT, Pezo L, Battino M, Sužnjević DŽ. Comparative analysis of antioxidant activity of honey of different floral sources using recently developed polarographic and various spectrophotometric assays. J Food Compost Anal. 2013;30(1):13-8. https://doi.org/10.1016/j.jfca.2012.12.004

73. Jerković I, Marijanović Z. Oak (Quercus frainetto Ten.) honeydew honey - Approach to screening of volatile organic composition and antioxidant capacity (DPPH ${ }^{\circ}$ and FRAP assay). Molecules. 2010;15(5):3744-56. https://doi.org/10.3390/molecules15053744 